\title{
CRÔNICAS ETNOGRÁFICAS DOS RITUAIS DE PROMESSAS KOIUPANKÁ, KARUAZU, KATOKINN E KALANKÓ ${ }^{1}$
}

\author{
SILOÉ SOARES DE AMORIM ${ }^{2}$ \\ $U F P B$
}

\begin{abstract}
RESUMO: Este artigo tem como objetivo expor alguns eventos que marcaram o trabalho de campo sobre os "arranjos" rituais e as promessas indígenas no processo de resistência e autoafirmação étnica dos Koiupanká, Karuazu, Katokin e Kalankó. Diante desses "arranjos" ou rituais de promessas, os povos em questão passaram por um árduo processo de "reaprendizagem" $e$, portanto, de conflitos internos entre diferentes práticas religiosas, resgates e (re)apropriação rituais. Neste processo de resistência e afirmação étnica, tiveram que negociar e ceder espaços cósmicos entre os rituais de matrizes africanas e indígenas que predominam entre eles. Neste sentido, o artigo, através dos dados etnográficos e das imagens apresentadas, pretende contribuir para uma compreensão dos rituais de promessas $e$ autoafirmação da identidade indígena no Alto Sertão alagoano, no processo de resistência étnicalindígena contemporâneo.
\end{abstract}

PALAVRAS-CHAVE: índios; promessas; rituais; identidade.

ABSTRACT: This article aims to expose a few events that have occurred during the field word on ritualistic "arrangements" and indigenous promises in the process of resistance and etnic self affirmation of the Koiupanká, Karuazu, Katokin and Kalankó people. Facing these "arrangements" or ritualistic promises, these people have experienced an arduous process of "relearning" -- therefore, internal conflicts between different religious practices, ritualistic rescue and (re)appropriation. In this process of resistance and etnic affirmation, they have had to negociate and lose cosmic space between the dominant rituals of African and indigenous matrixes. Based on the presented images and ethnographic data, we intend to contribute to comprehension of rituals of promises and indigenous identity self affirmation in the Alto Sertão of the state of Alagoas during the contemporary process of indigenous and etnic resistance.

KEYWORDS: indigenous people; promises; rituals; identity.

\footnotetext{
${ }^{1}$ Artigo adaptado do segundo capítulo - Parte II da tese de doutorado Os Kalankó, Karuazu, Koiupanká e Katokinn - Resistência e ressurgência indígena no Alto Sertão alagoano, apresentada ao Programa de Pós-Graduação em Antropologia Social do Instituto de Filosofia e Ciências Humanas da Universidade Federal do Rio Grande do Sul/UFRGS em 2010.

2 Doutor em Antropologia Social (UFRGS), docente do Centro de Ciências Aplicadas e Educação (CCAE), Departamento de Ciências Sociais (DCS), Curso de Antropologia, Universidade Federal da Paraíba (UFPB), Campus IV, Litoral Norte, Rio Tinto, PB. E-mail: siloe.amorim@gmail.com .
}

Espaço Ameríndio, Porto Alegre, v. 6, n. 1, p. 140-162, jan./jun. 2012. 
SILOÉ SOARES DE AMORIM - Crônicas etnográficas dos rituais de promessas...

No Poró, debaixo da pitombeira, foi pedido perdão por cantar os toantes às $4^{a}$ - feiras. Os toantes não podem ser chamados à toa, se chamar sem necessidade, fica todo mundo aí, parado. O toante é sagrado, é a identidade do Encantado, do Praiá, é o Praiá ${ }^{\text {. }}$

No transcurso destas crônicas, o leitor entenderá o sentido do pronunciamento acima feito pelos Karuazu, narrativas que marcaram o trabalho de campo voltado para os "arranjos" rituais e as promessas indígenas no processo de autoafirmação étnica dos índios Koiupanká, Karuazu, Katokinn e Kalankó no Alto Sertão Alagoano4.

A etimologia da palavra "promessa", a partir do catolicismo popular (QUEIROZ, 1976), indica um compromisso entre um santo milagroso e a pessoa que faz o pedido ao santo, seja ele de cura, de realização de um sonho etc. Daí o "pacto", a promessa, entre um e outro está consolidado e se materializa nos rituais que ocorrem entre o pedido, a realização do pedido e a dádiva, ou seja, a retribuição do santo; e, no caso dos índios em questão, dos Encantados, gerando, desta forma, uma hierarquização entre o grupo, a comunidade e a "força" ou o poder do Encantado, chamado também de Praiá.

\footnotetext{
${ }^{3}$ Notas isoladas feitas durante o trabalho de campo na casa de dona Eliete Karuazu, Campinhos, Pariconha, Alagoas, junho de 2009.

4 Etnias que pesquisei entre 1999 e 2009, o que resultou na tese de Doutorado. Descendentes dos Pankararu de Tacaratu e Petrolândia, Pernambuco, os Kalankó, Karuazu, Koiupanká e Katokinn migraram desde o século XIX para o Alto Sertão Alagoano e somente a partir de 1998 vêm reaparecendo no cenário étnico-político como índios resistentes ou ressurgentes com os etnônimos com que são atualmente reconhecidos. Como tais, demandam do órgão indigenista oficial, a FUNAI (Fundação Nacional do Índio), reconhecimento, delimitação e demarcação étnico-territorial. A forma particular como reapareceram (entre 1998 e 2002) marcou os quatro povos: uma aparição pública coletiva chamada "festa do ressurgimento". Apresentando-se de forma similar, mas em espaço físico e temporal distintos, o reaparecimento étnico dos Kalankó no Município de Água Branca, em 1998, com uma população de aproximadamente 350 pessoas; dos Karuazu de Pariconha em 1999, com mais ou menos 600 pessoas; dos Koiupanká em Inhapi, em 2001, com 585 pessoas e dos Katokinn, também de Pariconha, em 2002, com 700 pessoas, tem como pano de fundo o processo histórico e a trajetória (dispersão e reagrupamento) desses grupos como "rama" e "ponta de rama" dos Pankararu. A pesquisa de campo desenvolveu-se, paralelamente, no registro étnico/fílmico-fotográfico do processo de ressurgência destes povos, as festas de ressurgimento e as promessas. Esses rituais, primeiro, de ressurgência e depois, de promessas, são fundamentais na reconstrução e afirmação de seus etnônimos, concebidos e recriados a partir de uma necessidade de se autoafirmar, não somente frente à população sertaneja, mas principalmente, frente a FUNAI. Processo no qual os indivíduos e suas comunidades compõem sua própria forma de "mostrar-se" ao mundo com "novas" especificidades étnicas, numa tentativa de restaurar também sua memória étnica e indígena no Brasil contemporâneo. Contudo, estes índios, apesar de terem sido reconhecidos oficialmente pela Fundação Nacional do Índio em 2003 e de conseguirem alguma assistência fornecida pela Fundação Nacional da Saúde (FUNASA) e pela própria FUNAI, não obtiveram até o presente regularização fundiária, habitam ainda hoje pequenos lotes de terras dominiais, isto é, identificadas pelos grupos como tradicionais (AMORIM, 2010).
}

Espaço Ameríndio, Porto Alegre, v. 6, n. 1, p. 140-162, jan./jun. 2012. 
SILOÉ SOARES DE AMORIM - Crônicas etnográficas dos rituais de promessas...

Para os KKKK ${ }^{5}$, esta singularidade se refere à afirmação "identitária-ritual" atribuída à ascendência do Encantado "dono do terreiro", ou seja, trata-se do Praiá que "levantou o terreiro", isto é, do Encantado (primeiro) que deu origem (étnica de cada etnia ressurgida) e que se "apossou" do terreiro e do último (o derradeiro) que acompanha o primeiro. Para estes povos, "não existe o primeiro sem o derradeiro". Neste sentido, as promessas entre os KKKK envolvem aspectos de reorganização e pertencimento étnico, tendo como fundamento o levantamento de terreiros e dos Praiá como elementos afirmativos da identidade indígena frente à FUNAl, à sociedade local regional e, principalmente, frente ao próprio grupo.

Entre os KKKK, em seus terreiros, reconhecidos a partir do etnônimo de cada etnia, outros Encantados, após o ressurgimento, vêm "reaparecendo" aos poucos, representando desta forma, a sequência de entidades espirituais ou encantadas que retornam a seus espaços rituais, isto é, o terreiro de cada etnia constituída como rama ou ponta de rama Pankararu. Daí que o pressuposto de que "o primeiro não existe sem o derradeiro6". Essa metáfora na concepção simbólica entre os Kalankó, Koiupanká, Katokinn e Karuazu está profundamente ligada à continuidade étnica, ao fundamento ou "levantamento do terreiro" (de dança) em que são concretizadas as promessas aos Encantados. Estes, na oralidade pankararu, são os "mestres encantados", ou seja, são "caboclos velhos" que não morreram, se encantaram. Os encantados são, como afirma a cacique Nina Kotokinn, "espíritos vivos encantados", que, como uma "semente, voltou para ocupar seus terreiros". Como entidades espirituais, os Encantados têm nome e procedência ligados sempre à natureza ${ }^{7}$, aos quais os índios fazem pedidos e pagam promessas.

O pagamento da promessa fecha um círculo de dar, receber e retribuir. Uma vez feito o pedido e alcançada a graça, este momento, normalmente, vem repleto de significados, um deles é o de divulgar, pôr em circulação a graça ou os benefícios alcançados através do "milagre" e de seu benfeitor. Este aspecto, observado principalmente a partir das

\footnotetext{
${ }^{5}$ Para não repetir Kalankó, Karuazu, Katokin e Koiupanká, utilizarei KKKK para referir-me as quatro etnias em questão.

${ }^{6}$ Notas de Campo: Karuazu, campinhos, Pariconha, fevereiro de 2008.

${ }^{7}$ Conforme afirmam seu Antonio, pajé karuazu, e a cacique Nina Katokinn, fevereiro de 2008.
} 
SILOÉ SOARES DE AMORIM - Crônicas etnográficas dos rituais de promessas...

promessas indígenas karuazu e katokinn, nas quais os Encantados ou Praiá passaram a ser venerados, e, portanto, procurados para a realização de outros pedidos. Ressignificados pelos índios em questão, os Encantados, a partir de algumas promessas realizadas nas respectivas comunidades, passaram também a ser cada vez mais reverenciados por um número maior de pessoas, inclusive de outras etnias e também por não índios na região do Alto Sertão Alagoano, principalmente no Município de Pariconha, Alagoas, e adjacências.

É, portanto, a partir de tais relações e de reciprocidades, contempladas a partir do pedido, da dádiva ou da "graça alcançada", que são subtraídos os elementos que estruturam as "promessas" ou "pedidos" aos Encantados, conforme expressam o pajé, seu Antônio Karuazu, e a cacique Nina Katokinn: “... a gente tem que fazer o pedido com fé no Encantado, no Praiá e cumprir direitinho as obrigações" 8 . Contudo, jamais registrei nas promessas feitas pelos índios destas etnias uma reclamação, caso a dádiva não fosse retribuída pelo Encantado. Ao contrário, se o fazedor da promessa não cumprir com as obrigações, isto é, não pagar a promessa, este se sente em dever com a ou as entidades a qual fez o pedido em troca de uma "graça" e também com a comunidade a qual pertence.

Este aspecto primordial e singular indica que as pessoas que dão ou pagam a promessa ao Encantado não estão inseridas unicamente em um desejo individual de "dar" e "receber", mas sim em um contexto de satisfação do cumprimento da "promessa", que se faz com participação coletiva, ou melhor, comunitária, em que todos participam, deixando para um segundo plano o sentido individual, conforme afirma a cacique Nina Katokinn: de "tirar proveito do encantado". Assim, a realização ou a necessidade de estabelecer uma relação, uma aliança, entre o Praiá, o indivíduo e a comunidade é mais significativa do que ver satisfeito seu pedido, aspecto que vai de encontro à constituição de reciprocidades entre as entidades encantadas e as comunidades indígenas que zelam por estes preceitos. Princípios que vêm cada vez mais fortalecendo o grupo sociocultural, espiritual e politicamente frente à sociedade local e

\footnotetext{
${ }^{8}$ Cumprir com a promessa, manter o corpo limpo, ou seja, abster-se de prática sexuais, não beber bebidas alcoólicas, restrição alimentar entre outras abstinências dias antes e depois dos rituais. Notas de campo: pajé karuazu e cacique Nina Katokinn, Pariconha, fevereiro de 2008.
} 
SILOÉ SOARES DE AMORIM - Crônicas etnográficas dos rituais de promessas...

à FUNAl, que demandam destes sujeitos em processo de resistência étnica elementos formais, isto é, concretos de sua identidade étnica.

Teoricamente busco explicar minhas preocupações sobre o assunto observado e analisar, ao longo de uma das promessas, a de Clênio Karuazu - primeiro ritual de promessa que registrei entre estes povos $^{9}$-, as formas ou o processo de autoestima e afirmação étnica por meio das relações de afinidades com os Encantados, as etnias em questão e os Pankararu, etnia da qual descendem e da qual, ainda hoje, dependem para a realização e fortalecimento de certos rituais.

O componente que mantém o fluxo destas promessas indígenas na região são os elementos simbólicos (CASTRO, 2002) contidos nos ideais místicos dos índios da região e sua relação com os Encantados ou Praiás, ou seja, organização social, processo de cura, proteção por meio dos Encantados; respeito e a reverência - através das promessas e zelos - aos mesmos pela comunidade como forma de um contínuo étnico, tradicional, indígena. Portanto, a organização ou o sistema social destes grupos enfatiza um conjunto de representações coletivas. Este sistema, isto é, composição, distribuição espacial - e de papéis -, classificação (do batalhão de encantados), e inter-relação entre os grupos indígenas de diferentes etnias da região garantem a organização, o intercâmbio de valores e bens culturais (CASTRO, 2002), resistência, continuidade e práticas rituais, religiosas, considerando, neste caso, os valores transmitidos pelos pajés e mestres puxadores (cantadores) de toré e os próprios Praiá ou Encantados. Movimento pelos quais se organizam e atribuem sentido ao Batalhão de Encantados ${ }^{10}$ de cada etnia constituída e que dá sentido étnico a cada grupo ou comunidade indígena descendentes dos Pankararu, o que permite a autoafirmação étnicoreligiosa, cultural e social de cada comunidade. Tais aspectos, distribuídos através de meios simbólicos variados, atribuem valor à

\footnotetext{
${ }^{9}$ Entre as promessas que registrei (fílmica e fotograficamente), as mais significativas para a análise da autoafirmação da identidade étnica dos Koiupanká, Kalankó, Karuazu e Katokin foi a promessa de Clênio, em junho de 2001, a de dona Pedrina e de dona Enedina Koiupanká, em julho de 2002, e a de seu Pedro Katokinn, em junho de 2008 (AMORIM, 2010).

${ }^{10}$ Ao grupo de Encantados que pouco a pouco são resgatados no processo de reassentamento e/ou levantamento dos terreiros dá-se o nome de "batalhão", que protege a aldeia das forças antagônicas, organiza e dão sentido étnico-existencial ao grupo.
} 
SILOÉ SOARES DE AMORIM - Crônicas etnográficas dos rituais de promessas...

totalidade dos rituais (CASTRO, 2002) existente nas promessas indígenas visíveis em cada grupo através dos Praiás levantados ${ }^{11}$.

Metodologicamente, os dados etnofotografados (vídeo e fotografias) possibilitaram na análise dos elementos estéticos, temáticos e organizacionais dessas promessas, a partir das relações estabelecidas formalmente (das etnias) no trajeto étnico de afirmação e prática (dos rituais) entre eles. Após o reaparecimento ou ressurgimento, que prioriza o "levantamento" (ou criação) dos terreiros (de dança), o levantamento ou retomada (resgate) das sementes ou dos Encantados e seus toantes 12 e o estabelecimento de alianças entre o grupo, os encantados e a sociedade local, regional. Tais alianças - analisadas na perspectiva das teorias sócio-antropológicas -, a partir de uma "tríplice aliança": dar, receber e retribuir, os "laços de reciprocidades" com os quais Marcel Mauss (1924) interpreta em Essai sur le Don (ensaio sobre a dádiva) se inscrevem, na lógica das promessas aos encantados, numa "dependência" não unicamente de satisfazer uma necessidade pessoal ou do grupo, mas sim porque se torna imperativo marcar as regras dessas "obrigações" ou "pedidos", que são interdependentes entre o indivíduo, o grupo e o Encantado.

A dinâmica ritual dessas promessas transforma em "bem comum" o encantado e sua força, tornando-o simbolicamente eficaz (MAUSS, 1974, p. 138-140) coletivamente, o que contribui não só para a organização dos KKKK, mas, principalmente, para sua coesão, compreendendo, aqui, relações, ideias, crenças e o sentimento de pertencimento étnico, ou seja, em si, de alteridade.

As promessas a partir do tronco Pankararu e de suas ramas KKKK adquirem sentido análogo em termos de resgate e organização da

\footnotetext{
${ }^{11}$ O levantamento dos Praiá faz parte de um complexo sistema de resgate destas entidades - que antes estavam "adormecidas" ou "vagando de terreiro a terreiro" ou "vivendo nas matas, nas caatingas" e que passam, uma vez concebidas ou levantadas, a configurar, a representar e a organizar o grupo sócio, cultural e religiosamente.

${ }^{12}$ As entidades encantadas indígenas ou Praiá (caboclos ou índios velhos encantados que "não morreram, se encantaram") são representadas por uma semente (uma pedrinha, por exemplo) destinada a um membro do grupo que, ao encontrar esta semente, "deve cuidar bem dela". Este, ao encontrar a semente, indicada, às vezes em sonho ou apresentada por acaso em um momento particular - em um caminho, "caída do céu", no telhado da casa... -, este, a quem a semente se apresentou, passa a ser o dono da mesma, isto é, do Praiá ou Encantado. A partir deste momento, uma série de rituais são realizados para resgatar a identidade do Encantado: a veste de fibra de croá ou caroá, nome (do encantado), toante ou toré, o "moço" que veste o Praiá, entre outros rituais, fortalecendo assim a etnia e gerando hierarquias no grupo (AMORIM, 2010).
}

Espaço Ameríndio, Porto Alegre, v. 6, n. 1, p. 140-162, jan./jun. 2012. 
SILOÉ SOARES DE AMORIM - Crônicas etnográficas dos rituais de promessas...

alteridade, da resistência e continuidade étnica e vêm ganhado espaço em um amplo processo ritual entre os Encantados e o "pedinte da graça"; continuidade que é transferida de forma simbólica para toda a comunidade que se envolve neste processo, fortalecendo física e espiritualmente tanto um como outro, ou seja, o indivíduo, seu grupo familiar e toda a comunidade de modo geral, frente também à população local.

Com relação à organização das promessas indígenas e seu sentido "dar, receber e retribuir" - ou seja, nesta aberta trilogia, melhor dito, situação -, de acordo com as teorias estruturalistas (LÈVI-STRAUSS, [s.d.]), o que fundamenta a essência ou a estrutura de um grupo social é a formalização da própria ideia de "estrutura", ou seja, aspectos estáveis e relevantes na composição social de um grupo, em oposição ao que é instável, ocasional, isto é, a instalação dos elementos ou partes de um todo. As formas como esses elementos ou suas partes se relacionam entre si é o que determina à natureza simbólica das características, da função ou do funcionamento dos eventos sociais, inter-relacionados aos rituais (CAILLÉ, 2002), por exemplo, da promessa, como parte de um contínuo étnico.

O modo como estes rituais ou estas promessas são organizadas dentre estas etnias, desde uma perspectiva - ou uma análise - a partir do ressurgimento, indica, empírica e especificamente, em sua estrutura ritual, o grau de pertencimento e autoafirmação necessários da continuidade étnica em função das instituições religiosas básicas (próprias) e das atividades sociais; relações que fortalecem o sentido de autonomia que reivindica cada uma delas.

A estrutura social, relacional, isto é, o núcleo das promessas, se baseia na organização e formalização dos rituais ou dos "pedidos de graça" em um sistema coerente de relações que forma o alicerce ou a dinâmica na qual residem aspectos variáveis dos fenômenos de inter-relações (negociações nos rituais) interpessoais hierarquicamente definidos entre os indivíduos, a comunidade e o tronco (Pankararu). Na prática, esses fenômenos (as promessas) são tomados como atributos da realidade interna de cada etnia e o processo relacional estabelecido entre eles. 
SILOÉ SOARES DE AMORIM - Crônicas etnográficas dos rituais de promessas...

O conjunto que forma a realização dos rituais de promessas indígenas - no caso dos KKKK -, configurados na "mesa"13, na dança, no canto, na concepção de "sementes" (Praiá) e seus toantes, somando as oferendas ${ }^{14}$ e a satisfação dos indivíduos comprometidos em tais rituais, constituem os elementos que dinamizam as promessas; enquanto suas partes, ou seja, as etapas de sua organização, dão, etnicamente, sentido às oferendas organizadas espacialmente nos terreiros, frente à casa dos donos do Praiá, no poró, isto é, casa dos homens ou encantados ${ }^{15}$, e até mesmo na paróquia local16. O aspecto temporal, a data (a escolha do mês, do dia da semana, por exemplo), é planejado e representa trocas sociais, econômicas, culturais e religiosas que derivam das relações com diferentes sujeitos: o pajé ou a "mestre de mesa" - que recebe ou encarna os encantados -, puxador(a) de toré, rezador(deira) de novena, o pároco local, os convidados índios de outras etnias e seus acordos com outros grupos sociais (políticos, religiosos) que apóiam a realização do ritual ou dos rituais com bebidas (geralmente garapa de cana-deaçúcar), fumo, alimentos, transportes. Elementos que enfatizam as dimensões sociológicas que caracterizam certos rituais e suas propriedades, ou seja, regras que indicam, em geral, as condições inerentes aos rituais dos Praiá ou Encantados, considerados, substancialmente, como núcleo que estrutura estes pedidos.

Estes pedidos, em lugar, por exemplo, de serem feitos a um santo católico, são feitos aos Encantados. Para que seja validado cada um dos pedidos ou recebimento da graça, o pedido vem calcado com um enredo, uma trama que principia cada pagamento da promessa ou oferenda aos Praiá - o que irá depender das condições do "pedinte".

\footnotetext{
${ }^{13}$ A "mesa" ou "trabalho de mesa", isto é, concentração espiritual na qual índios e entidades encantadas se comunicam em uma comunicação direta, na maioria das vezes em busca de soluções para seus conflitos cósmico-terrenais, espirituais, morais, sociais.

${ }^{14}$ As oferendas neste sentido fazem parte de uma necessidade relacional do grupo e seus indivíduos com as entidades encantadas em oferecer, por exemplo, um prato (almoço) a um (ou aos) Praiá, o que implica também em rituais de dança coletiva, defumação das vestes, enfim, cuidados do ou dos Praiás, ou seja, relação direta que oferece um processo contínuo de práticas étnicas.

${ }^{15}$ Espaço sagrado onde os moços que vestem o Praiá se relacionam diretamente com os mesmos, espaço restrito às mulheres e gente de fora. Neste espaço a veste do Praiá é arejada, defumada e tratada pelo moço que o veste, cujo rosto ninguém deve ter conhecimento (da pessoa que veste o Praiá). Uma vez nas vestes do encantado, o moço "torna-se" o próprio Praiá e ninguém deve revelar esta informação, é "um segredo". Este só não é vetado aos moços que fazem parte do batalhão de Praiás e não deve ser revelado nem comentado entre eles quem é quem.

${ }^{16} \mathrm{Em}$ alguns momentos, alguns rituais (de dança, por exemplo, de toré) são praticados frente à paróquia local.
}

Espaço Ameríndio, Porto Alegre, v. 6, n. 1, p. 140-162, jan./jun. 2012. 
SILOÉ SOARES DE AMORIM - Crônicas etnográficas dos rituais de promessas...

Seja esta uma condição econômica ou religiosa, ela tem uma ligação com um zelador de Praiá (moço ou o dono do Praiá) ${ }^{17}$ ou com o próprio pajé ou mestrel 8 , que lida diretamente com estas entidades. Todo este fenômeno segue uma lógica sequencial baseado na existência ou no levantamento do Praiá, cujo dom corresponde a cumprir um pedido, a fé no Encantado e a proteção deste e as condições materiais de reciprocidades.

Neste principal aspecto, pela própria lógica do ritual de promessa, que demanda a participação comunitária, coletiva, é imperativo, o que pode ser, inclusive, visto como uma forma de auxílio inter-relacionados com diferentes grupos sociais (políticos e comerciantes) locais e outras comunidades indígenas com afinidades socioculturais, religiosas e de parentesco, o que formaliza o ciclo das promessas - "pedir", "dar" e "receber" - e traduz um sentido cósmico interligado sócio, cultural e religiosamente. Esses elementos foram observados através dos participantes (de forma direta ou não) das promessas - especificamente nas de Clênio, dona Pedrina, Enedina Koiupanká e seu Pedro Katokinn -, nas quais era notória a presença ou aglutinamento de vários seguimentos étnicos, religiosos, sociais e culturais expressos tanto na fé cristã como na de matrizes afroindígenas aos costumes locais, regional. Tais "arranjos" completam ou formam uma incrível dimensão entre os Encantados, a comunidade indígena ou o povo e a relação com a fé cristã. Aspectos conformados ou adotados, em partes, pelas relações sucessivas formadas e estabelecidas pelas diásporas, pelos fluxos étnicos e a necessidade de se autoafirmar diante das condições históricas (tradicionais) do indigenismo nacional, no qual se inscrevem as redes de relações sociais

\footnotetext{
${ }^{17}$ Existe uma hierarquia sócio-ritualística neste processo: o dono do Praiá é aquele ou aquela que acha, que "recebe" o Praiá, a semente. Este torna-se o dono do Praiá, do encantado, chamado também de mestre. A partir do momento que lhe é dado, ou que ache a semente, o dono terá que providenciar um "moço" que dance e vista o Praiá, que o ajude a cuidar. Estabelece-se neste sentido, uma simbiótica relação entre estes sujeitos. O dono pode ter mais de um Praiá, o que faz com se torne uma pessoa importante no grupo. Começa, a partir do recebimento da semente, um processo ritual com o pajé, o Praiá e o dono. Neste processo, o arquétipo, a identidade do encantado, é revelado, o nome, o toante (toré), etc. A partir de então, o Praiá deve ser batizado, isto é, levado ao terreiro de dança, e passa a fazer parte do batalhão de Praiás. O nome, no trabalho de mesa, que lhe é atribuído é como passa a ser chamado: Mestre Andorinha, Mestre Gavião, etc. O nome de um Praiá está relacionado ao arquétipo do encantado.

${ }^{18}$ Mestre é aquele também que lida com os encantados (além do pajé e dos puxadores de toré), são pessoas que recebem, encarnam o encantado e participam nas intermediações entre o individuo, a comunidade, e o Praiá.
}

Espaço Ameríndio, Porto Alegre, v. 6, n. 1, p. 140-162, jan./jun. 2012. 
SILOÉ SOARES DE AMORIM - Crônicas etnográficas dos rituais de promessas...

que constituem a estrutura do ressurgimento étnico indígena dos KKKK no Brasil contemporâneo. Aspectos visíveis - e de uma beleza e estética ímpares - observados primeiramente na promessa de Clênio Karuazu e, posteriormente, nas já citadas dos Koiupanká e Katokin. Respectivamente, estas promessas aconteceram nos meses do ano que correspondem à fartura nas comunidades devido à época de chuva para o plantio e colheita, pastagem para os animais e vendas de produtos agrícolas excedentes na região, temporada que permite maior participação e trocas entre as comunidades e o comércio local.

Sendo a promessas de Clênio Karuazu o primeiro ritual (de promessa) deste tipo entre os KKKK, uma imensa rede de relações começa a fluir entre os índios ressurgidos no Alto Sertão Alagoano, seus descendentes e outras etnias da região que passam a venerar e fazer promessas aos encantados. Elementos sócio-religiosos que considero fundamental para a afirmação da autoimagem das etnias aqui referidas, ao mesmo tempo em que, a partir destas relações de promessas, estabelecem-se interações com grupos sociais locais e estreitamentos de laços parentais indígenas da região.

No caso da promessa de Clênio, este recebeu a graça: uma indenização. Ao ser demitido de seu trabalho em São Paulo, fez um pedido ao Mestre Encantado, dono da Aldeia Karuazu, o que está de frente do Batalhão de Praiá. A promessa consistiu em levar os Praiá (o batalhão) para o terreiro e oferecer um almoço. A oferenda, neste primeiro caso, consistiu, no caso de Clênio, como uma prova de crença e fé nos encantados e na força do dono do terreiro, o Mestre Kancacarezinho, ao conceder a "graça" a Clênio, e este em oferecer um "prato" (almoço) aos encantados, com participação de toda a comunidade. Aspectos de reciprocidades que marcam, para os Karuazu, a afirmação da etnia perante a sociedade indígena local e a proteção dos encantados. Estes, doravante, passam a ser procurados e reverenciados também por indígenas de outras etnias e também por devotos não indígenas que veem nos encantados forças reparadoras de males espirituais e materiais, ou tão somente como forma de reconhecimento das forças espirituais dos encantados indígenas ou que deles derivam. 
SILOÉ SOARES DE AMORIM - Crônicas etnográficas dos rituais de promessas...

\section{A promessa de Clênio Karuazu em imagem: considerações finais}

$\mathrm{Na}$ organização destes rituais - conforme narram as imagens da promessa de Clênio Karuazu no final deste artigo -, existe não somente um aspecto estético a ser observado, cumprido, mas, também e principalmente, o processo organizacional do ritual. Como já dito, os argumentos desses rituais partem de uma lógica individual do pagador da promessa, que se estende para toda a comunidade, o que deixa claro o potencial étnico-organizacional, possível somente a partir de experiências criativas, fundamentadas em lógicas que ultrapassam a ideia de cumprimento ou realização da promessa pelo pagador, ou, ao contrário, do cumprimento do Encantado ao pagante. Esse processo é, a priori, "desconsiderado" pelo pagador. O que é importante para ele é sua fé na proteção e o reconhecimento do Encantado, cujo retorno deste último, ou recompensa, em um futuro mais ou menos próximo, para o "pagante" e o grupo, pode se transformar em inúmeros benefícios, e não necessariamente no cumprimento imediato (do encantado) da promessa, situação que estimula a fé e o compromisso entre o encantado, o pagante e a comunidade, que pede cada vez mais proteção ao seu benfeitor encantado, fortalecendo e estendendo os laços de solidariedade, fé e reciprocidade entre o indivíduo, o batalhão de encantados e as redes de relações criadas através destes rituais.

Este contexto, estabelecido sócio, cultural, espacial e temporalmente, contribui com a finalidade última sintetizada na devoção ou reverência aos encantados. Rituais concernentes à graça concedida a um membro da comunidade pelos próprios encantados e cujas sementes foram desenvolvidas em terreiro próprio de cada etnia descendente dos Pankararu. Eventos que remetem normalmente a uma série de tramas e interações interpessoais e comunitárias repletas de circularidades étnicas e mágico-religiosas que são atribuídas ao pagador da promessa e a comunidade à qual pertence. A forma como estes rituais são representados no terreiro e a complexidade organizacional para sua realização envolvem aspectos análogos, relacionados ao levantamento dos terreiros de dança conformados em cada aldeia. Uma vez levantados estes terreiros, os mesmos são legitimados pelo batalhão de encantados, que, através do pajé ou 
SILOÉ SOARES DE AMORIM - Crônicas etnográficas dos rituais de promessas...

mestres, dependendo da forma como estes rituais são representados, o terreiro é aberto ao cosmo e fica vulnerável às forças mágico-religiosas para receber todas as forças de todos os encantados.

Desenvolvidas, "transformadas" e reconfiguradas nos processos sociais das experiências dos KKKK e suas comunidades, as promessas envolvem o mestre guia ou "dono" do terreiro e se dão em um espaço ritual idealizado a partir das próprias etnias já com seu etnônimo ampliado, decorrente do ressurgimento ou reaparecimento étnico. Particularidade antes realizada raras vezes pelos KKKK nos terreiros dos Pankararu, pois, como disse, então, seu Antonio, pajé karuazu, "antes da festa do ressurgimento", dependiam dos mestres, puxadores de toré, dos trabalhos de mesa, que só podiam ser realizados intermediados pelo pajé ou mestres, nos terreiros e com os Praiá pankararu. A partir da Promessa de Clênio, tais rituais são realizados pelos Karuazu, e seus Praiá reverenciados em terreiro próprio. Fato compreendido entre os Kalankó, Karuazu, Katokinn e Koiupanká.

Esses rituais, para estas etnias, obedecem a uma lógica de integração cósmica terrenal entre os Encantados, o Terreiro e a comunidade, "tornando-se um só elemento". Os Praiá e seus elementos (toré, toantes, vestes, o moço, o poró, as promessas) são aglutinações étnicas que dão sentido à etnia. Identidade étnico, social e religiosa representada na figura ou proteção do dono (mestre e seu batalhão) do terreiro, que protege de malefícios este "todo" étnico. Aspecto somente dinâmico e eficaz em dada etnia devido ao fato de que envolve elementos sagrados gerados no seio do próprio saber de cada povo e a criação dos espaços sagrados como o terreiro, o poró, a casa dos "homens encantados", entre outros espaços e objetos importantes para a realização de rituais, sejam de promessas, de dança ou tão somente de acolhida ou veneração do Encantado. Elementos que indicam um processo organizacional ímpar da identidade étnica dos e entre os Katokinn, Koiupanká, Kalankó e Karuazu de forma autônoma, na qual a participação de outros grupos e do próprio tronco (Pankararu) se dá numa formalidade social de reciprocidades e solidariedade étnica e, principalmente, de afinidade, ou seja, a partir das relações estabelecidas entre parentes e afins e a força do encantado evocado como parte de recuperação da memória ancestral do grupo reconfiguradas e 
SILOÉ SOARES DE AMORIM - Crônicas etnográficas dos rituais de promessas...

ressignificadas em práticas étnicas indígenas e o que estas significam na realidade contemporânea dos povos indígenas no Brasil.

\section{CRÔNICAS VISUAIS DA PROMESSA DE CLÊNIO KARUAZU 15 DE JUNHO DE 2001}

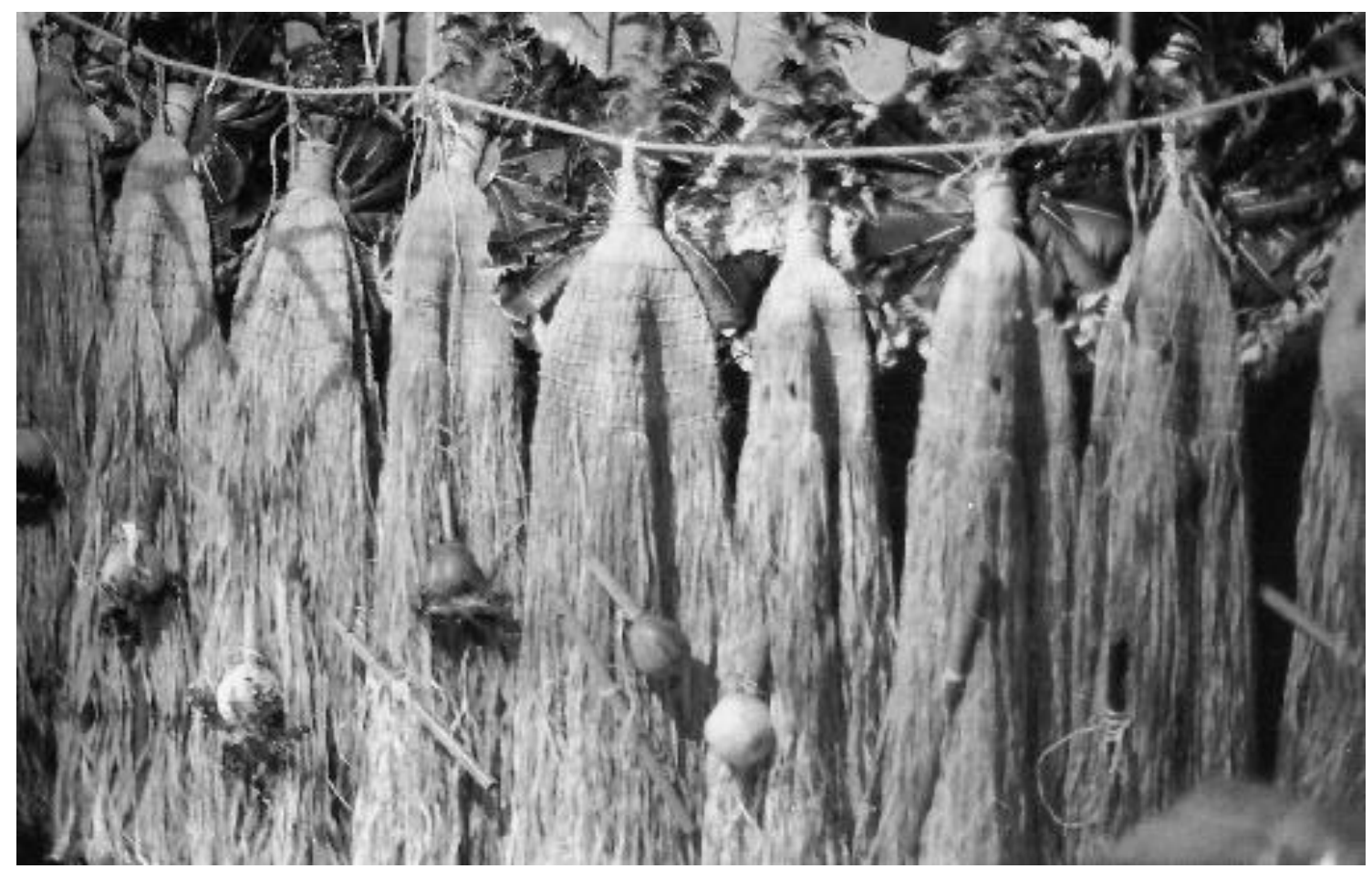

\section{Imagem 01}

Os Praiá são guardados na "Casa dos homens encantados", que fica ao lado da casa do pajé e em frente ao terreiro karuazu (de Campinhos, Pariconha, AL). Neste espaço, os moços, quando tiram as vestes do Praiá, voltam com a as mesmas, que são penduradas em fileira. Os utensílios pendurados (na parte superior da veste), o maracá e a flauta, instrumentos musicais, via de comunicação para invocar os encantados, e carteira de cigarros ou pedaço de fumo em rolo são utensílios do Praiá utilizados pelo moço que o veste no terreiro. 
SILOÉ SOARES DE AMORIM - Crônicas etnográficas dos rituais de promessas...
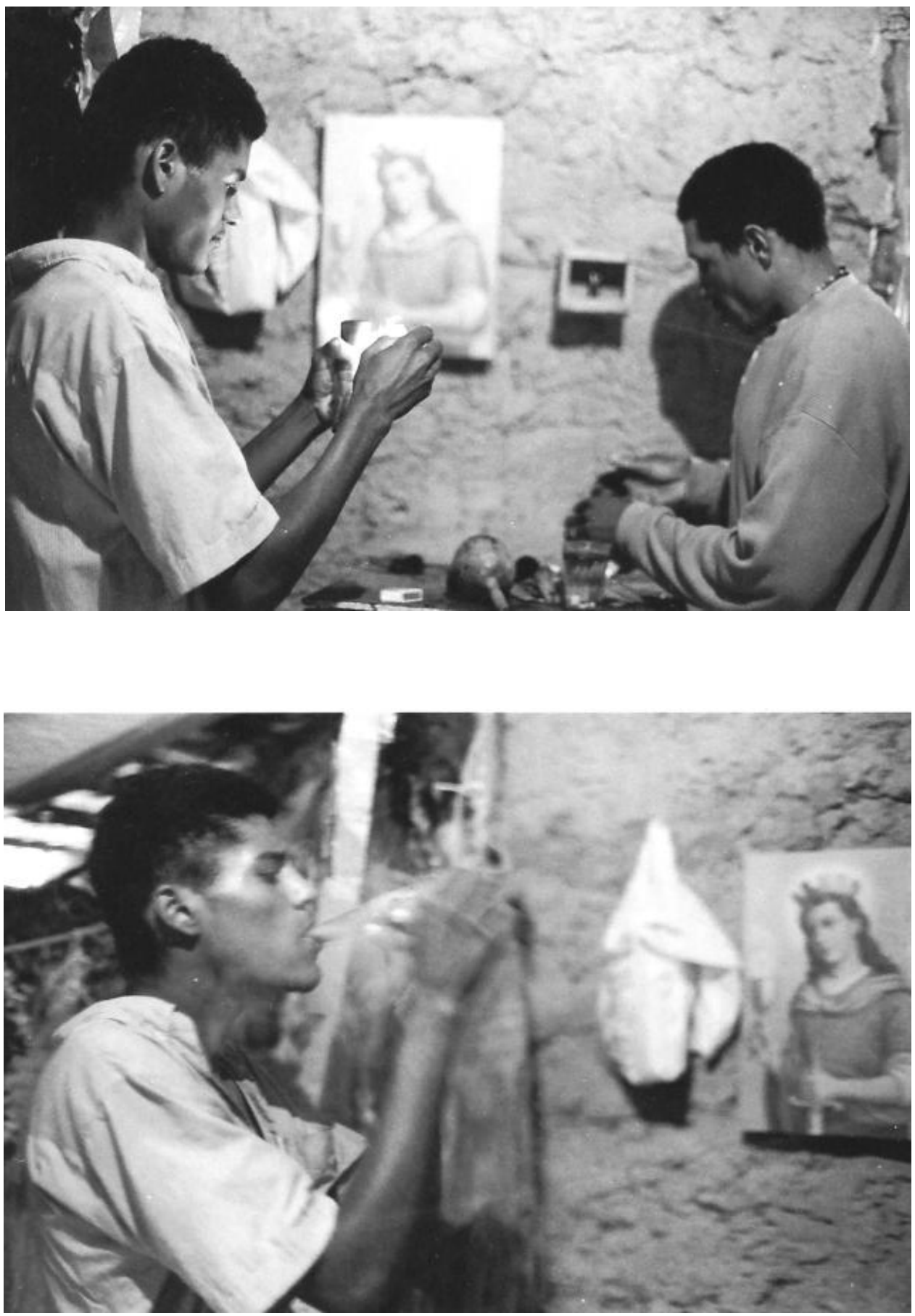

Imagem 02

Interior da casa dos Praiá, Beto e Zé Arnaldo (mestres puxadores de toré) nos preparos para defumar ou purificar com fumo as vestes dos encantados e o terreiro.

\section{Imagem 03}

Detalhe de Beto acendendo o campiô - cachimbo feito de madeira para defumar as vestes dos Praiá.

Espaço Ameríndio, Porto Alegre, v. 6, n. 1, p. 140-162, jan./jun. 2012. 


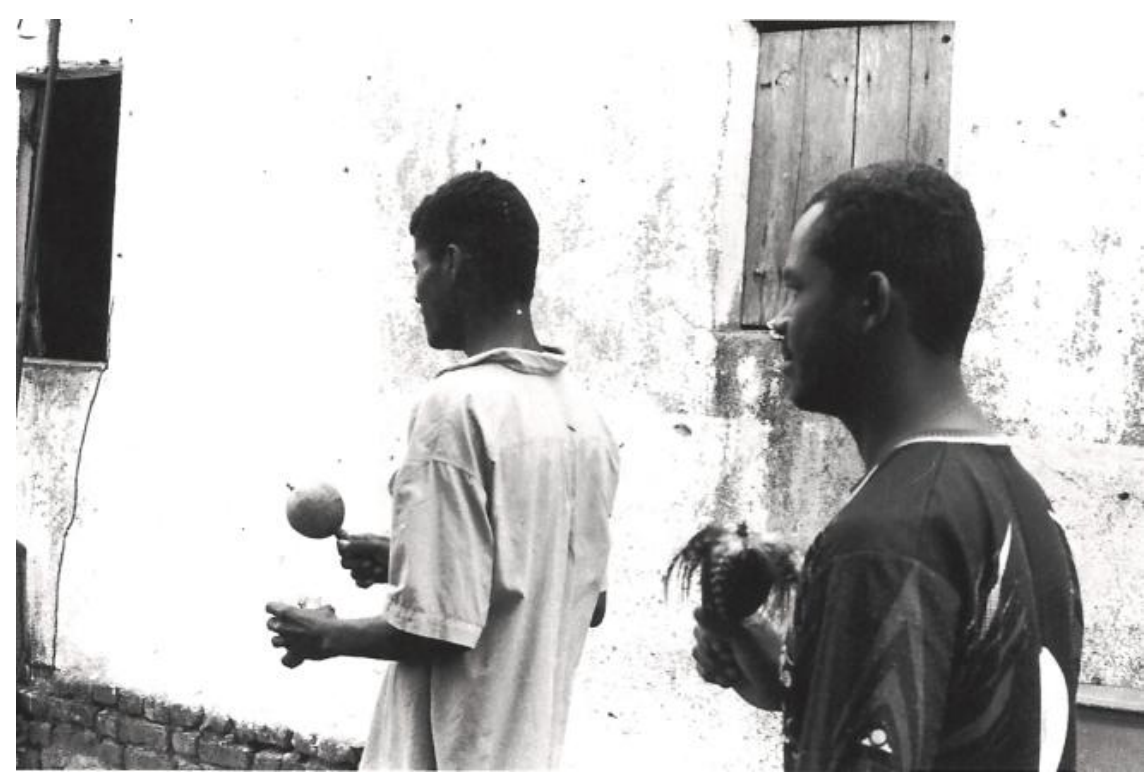

\section{Imagem 04}

Encruzando ou cruzando o terreiro antes de ser aberto pelos Praiá. A ação consiste em incensar o terreiro e arredor em repetições sonoras do maracá e sons emitidos vocalmente por três vezes ou três voltas (no terreiro, faz-se o sinal da cruz) e purificase o terreiro.

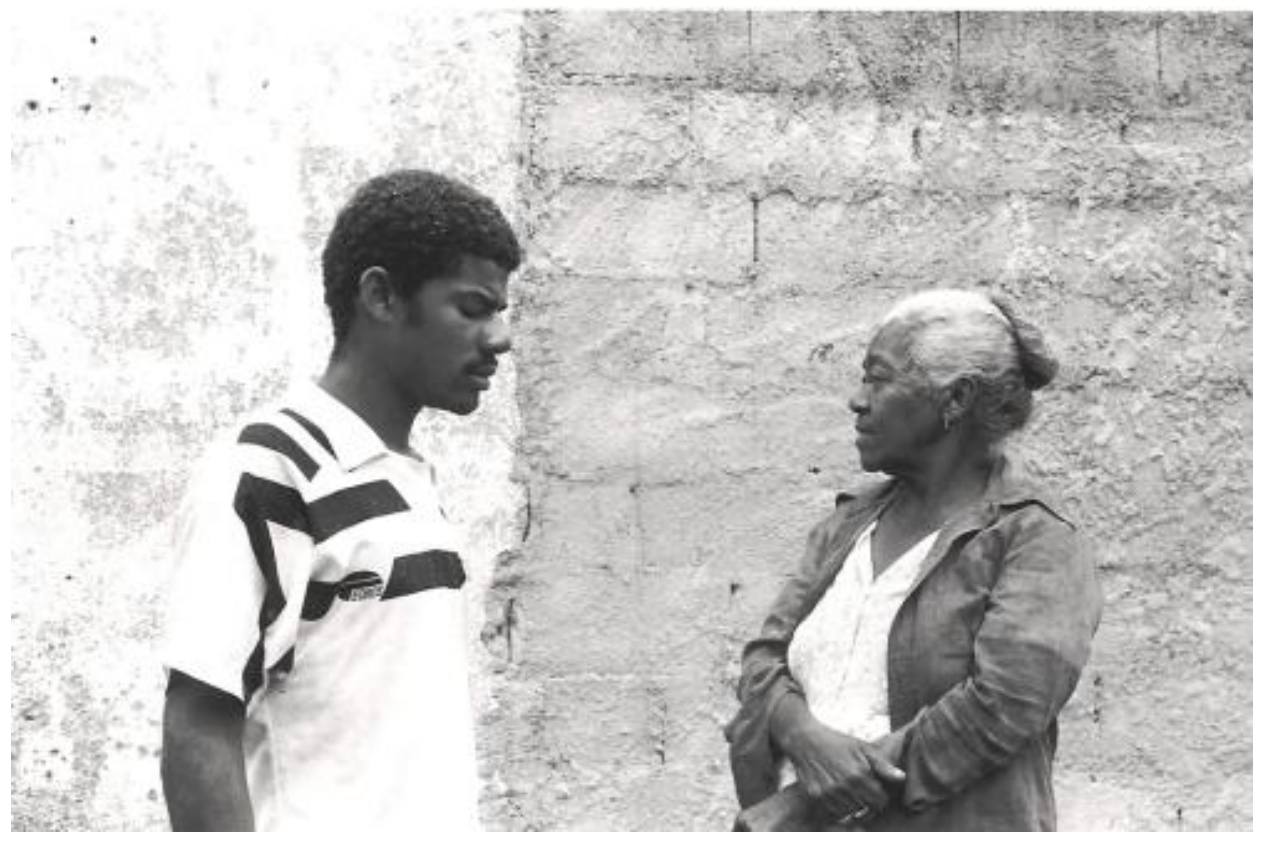

\section{Imagem 05}

Clênio e dona Aliete (avó de Clênio) Karuazu conversando.

Espaço Ameríndio, Porto Alegre, v. 6, n. 1, p. 140-162, jan./jun. 2012. 


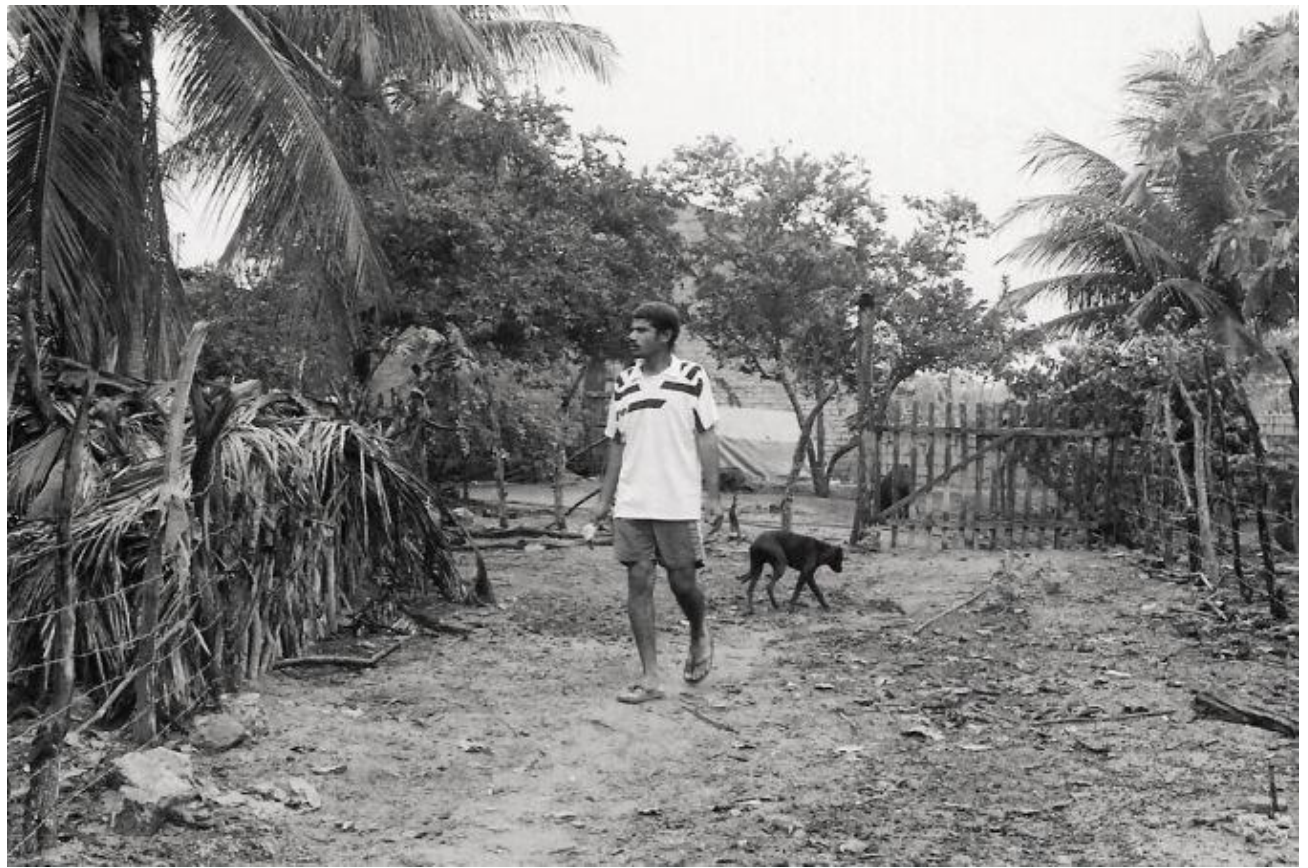

Imagem 06: Clênio sai nas primeiras horas da manhã em busca do animal a ser abatido para o almoço dos Praiá.

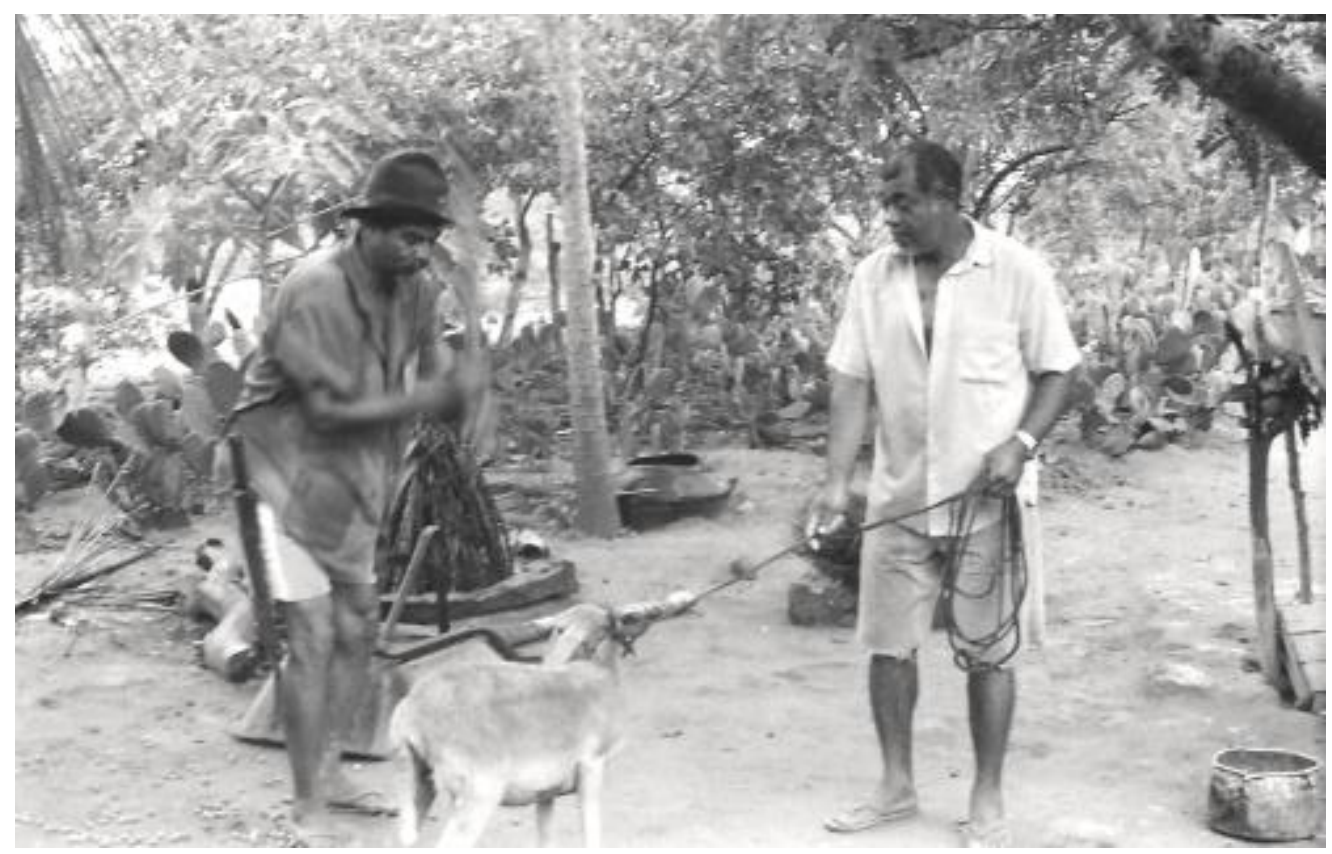

\section{Imagem 07}

Da esquerda para a direita: Jerônimo, pai e padrinho (da promessa) de Clênio, e o pajé, seu Antônio Karuazu, tio de Clênio, irmão de Jerônimo, cacique karuazu de Campinhos, levando o animal para o abate.

Espaço Ameríndio, Porto Alegre, v. 6, n. 1, p. 140-162, jan./jun. 2012. 
SILOÉ SOARES DE AMORIM - Crônicas etnográficas dos rituais de promessas...
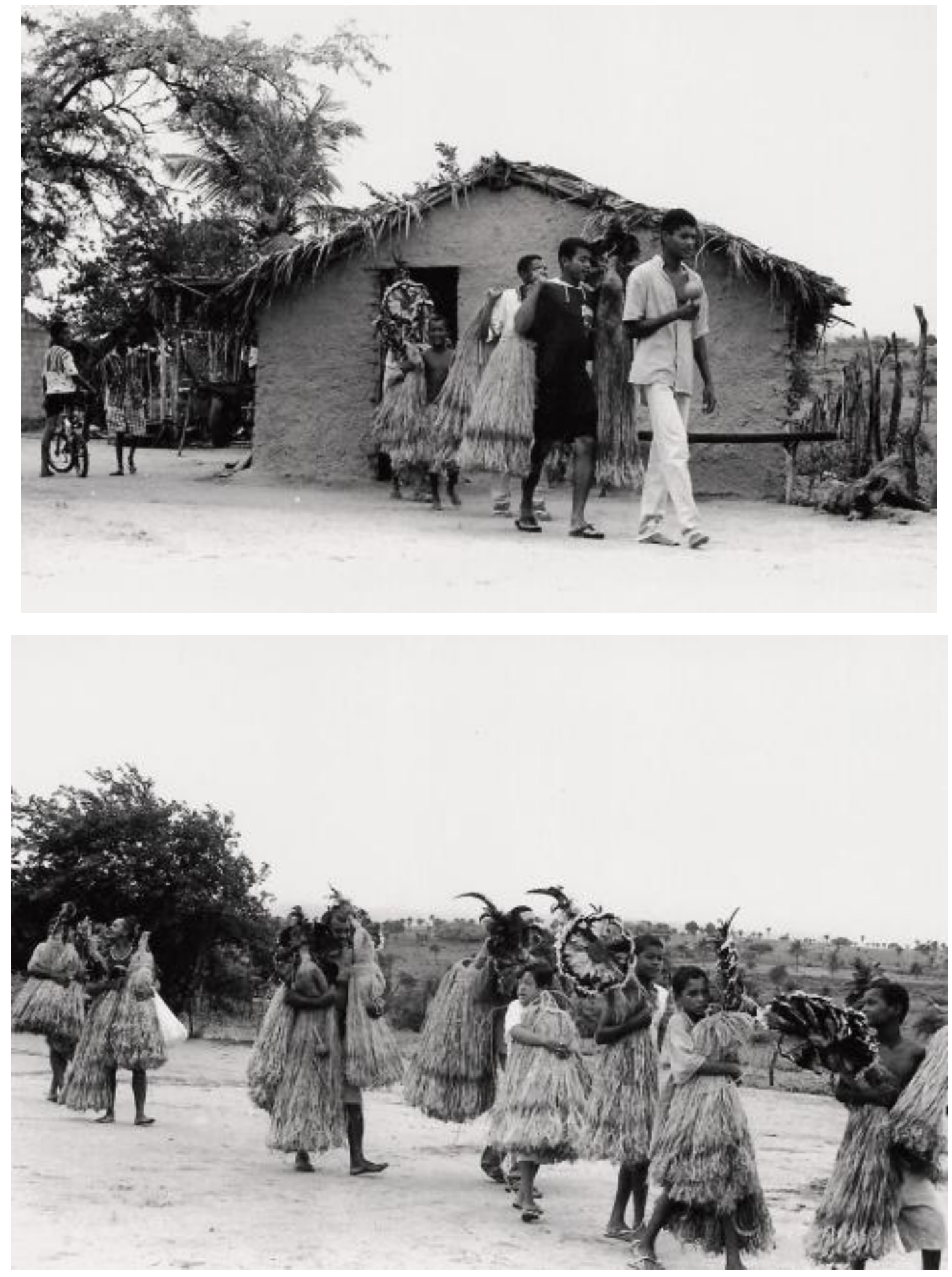

Imagem 08 e 09

Saída dos Praiá (vestes) da "casa dos homens" para o poró. Ao som do maracá e entoando toantes ou toré, o puxador guia os moços (que vestem os Praiá) para o poró, espaço de sociabilização e cuidados do Praiá. No poró, os moços vestem o Praiá e entoam toantes, tocam flauta e maracá, chamando os encantados.

Espaço Ameríndio, Porto Alegre, v. 6, n. 1, p. 140-162, jan./jun. 2012. 
SILOÉ SOARES DE AMORIM - Crônicas etnográficas dos rituais de promessas...
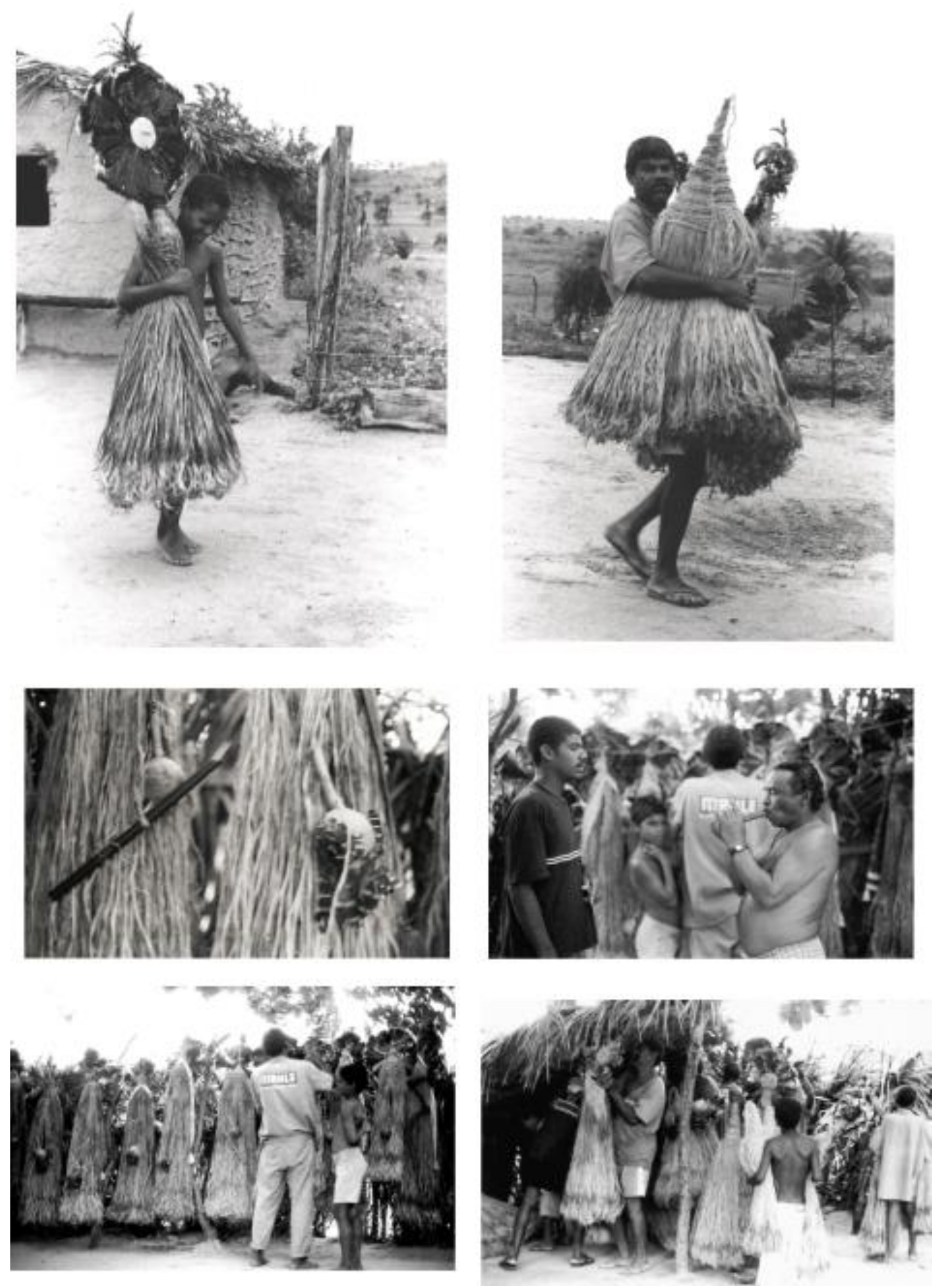

Espaço Ameríndio, Porto Alegre, v. 6, n. 1, p. 140-162, jan./jun. 2012. 


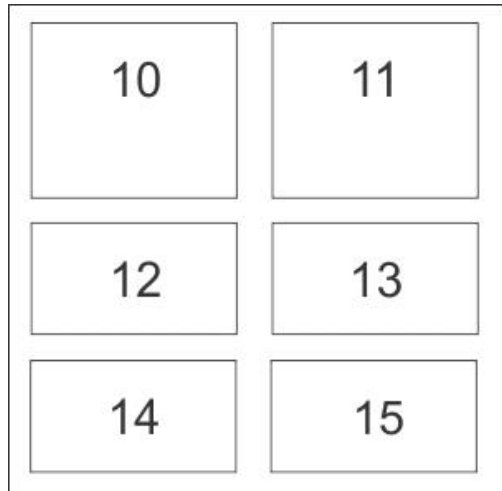

\section{Imagem 10}

Detalhes da saída das vestes do Praiá.

\section{Imagem 11}

Jerônimo carrega uma das vestes.

\section{Imagem 12}

No poró: detalhes das vestes e apetrechos dos Praiá.

\section{Imagem 13}

Clênio sendo defumado no poró por um mestre puxado de toré e zelador (dono) de Praiá.

Imagem 14 e 15

Jerônimo, o padrinho, com a ajuda de um garoto que também veste um Praiá, pendura, arruma e estira as vestes para serem purificadas, benzidas com o campiô.

Espaço Ameríndio, Porto Alegre, v. 6, n. 1, p. 140-162, jan./jun. 2012. 
SILOÉ SOARES DE AMORIM - Crônicas etnográficas dos rituais de promessas...
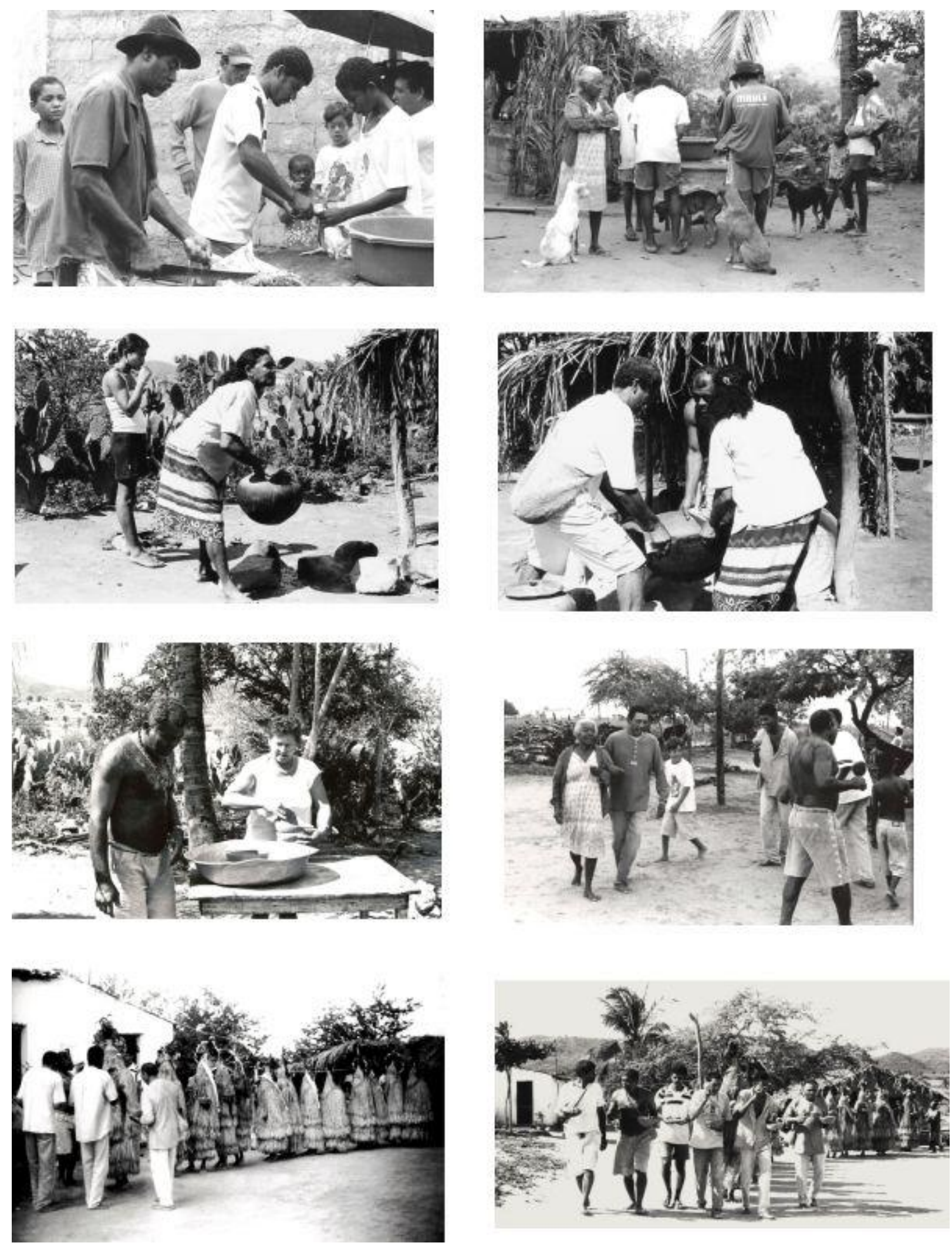

Espaço Ameríndio, Porto Alegre, v. 6, n. 1, p. 140-162, jan./jun. 2012. 
SILOÉ SOARES DE AMORIM - Crônicas etnográficas dos rituais de promessas...

\begin{tabular}{|l|l|}
\hline 16 & 17 \\
\hline 18 & 19 \\
\hline 20 & 19 \\
\hline 20 & 21 \\
\hline 22 & 23 \\
\hline & 23 \\
\hline
\end{tabular}

\section{Imagem 16}

Detalhes do tratamento (corte e limpeza) do animal abatido por Clênio e Jerônimo. Momento de grande sociabilização da comunidade.

\section{Imagem 17,18,19, 20}

Detalhes da preparação do fogo e das panelas para o guiso da carne (de ovelha). Todas as etapas do ritual são efetivadas por pessoas preparadas para esta finalidade, normalmente estas pessoas ocupam posição de hierarquia ritual dentro do grupo e devem abster-se de sexo, bebida e outros elementos profanos, normalmente, por três dias antes e três dias depois do ritual. De acordo com o pajé Antônio Karuazu, os preparos, neste caso, são feitos pelo pajé, pelo padrinho e donas ou zeladoras de Praiá com mais de 45 anos.

\section{Imagem 21}

Em vários momentos, no decorrer do dia, dá-se um processo de sociabilização e recreação através da dança do toré. Enquanto uns preparam a comida, varrem o terreiro, defumam no poró as vestes dos encantados, cozinham, fazem a garapa de cana-de-açúcar ou água açucarada, dependendo da posse do padrinho da promessa, outros dançam nas beiras do terreiro.

\section{Imagem 22}

Oferenda - o almoço - dos Praiá e da comunidade. Antes desse momento, o terreiro é encruzado pelos encantados (quando estes saem do poró), que dançam vários toré. Ao meio-dia, é dado o almoço. Os Praiá encruzam o terreiro outras três vezes e voltam para o poró, onde comem e bebem garapa. Neste ínterim a comunidade recebe também o almoço. Algum tempo depois de comer e descansar no poró, os Praiá voltam para o terreiro. Momento depois começa o toré coletivo e, no final da tarde, a "entrega" é feita: momento simbólico no qual o dono da promessa é entregue aos Praiá e por todo o batalhão é encruzado ou benzido. Um por um dos Praiá benze com parte de sua veste o que faz a promessa, este ritual é feito também pelos puxadores de toré ao som dos maracá, toantes e toré. Depois, os encantados fecham o terreiro, voltam para o poró e são levados de volta para a "casa dos homens" e só saem de vez em quando para serem arejados e defumados no poró ou para participar de outros rituais.

\section{Imagem 23}

Cruzamento do terreiro antes de ingerir o alimento.

Espaço Ameríndio, Porto Alegre, v. 6, n. 1, p. 140-162, jan./jun. 2012. 
SILOÉ SOARES DE AMORIM - Crônicas etnográficas dos rituais de promessas...
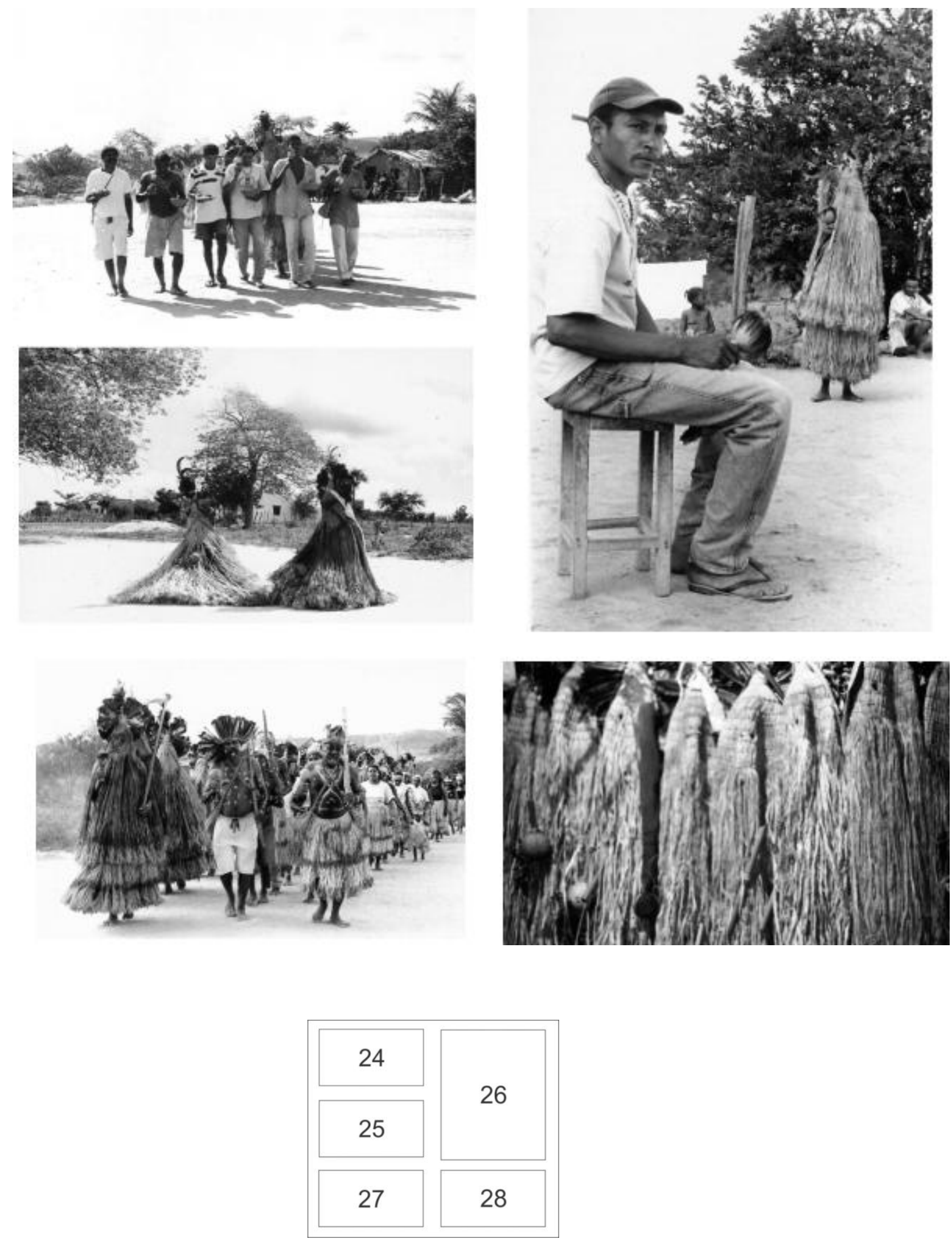

Imagem 24

Cruzamento do terreiro antes de ingerir o alimento.

Espaço Ameríndio, Porto Alegre, v. 6, n. 1, p. 140-162, jan./jun. 2012. 


\section{Imagem 25}

"Descanso do Praiá": durante o ritual, que é muito puxado, os moços que vestem o Praiá descansam no terreiro.

\section{Imagem 26}

Zé Arnaldo, o puxador de toré dos Karuazu de Campinhos.

\section{Imagem 27}

Toré coletivo: depois desse momento, a "entrega" é feita e os Praiá voltam para a "casa dos homens". Na frente, da esquerda para a direita, o encantado, dono do terreiro, o padrinho e o pajé. O moço, o pagador da promessa, está reservado, esperando no poró o momento de ser "entregue" aos Praiá para ser encruzado.

Imagem 28

Os Praiá estão de volta, são guardados na "casa dos homens".

\section{Referências bibliográficas}

AMORIM, Siloé Soares de. Os Kalankó, Karuazu, Koiupanká e Katokinn Resistência e Ressurgência Indígena no Alto Sertão Alagoano. 2010. 314 f. Tese (Doutorado em Antropologia Social) - Universidade Federal do Rio Grande do Sul, [2010].

CAILLÉ, Alain. Antropologia do Dom: o terceiro paradigma. Petrópolis: Vozes, 2002.

CASTRO, Eduardo Viveiros de. A inconstância da alma selvagem. São Paulo: Cosac \& Naify, 2002.

LÈVI-STRAUSS, Claude. Antropologia Estrutural. Rio de Janeiro: Tempo Brasileiro. [s.d.].

MAUSS, Marcel. As técnicas do corpo. In: Sociologia e Antropologia: com uma introdução à obra de Marcel Mauss, de Claude Lévi-Strauss. São Paulo: Edusp, 1974, p. 138-140.

QUIEROZ, Maria Isaura Pereira. O messianismo no Brasil e no mundo. São Paulo: Alfa Omega, 1976. 